$\underline{\text { Research Article }}$

\title{
Clinical Response of Convalescent Plasma Therapy in COVID-19 Patients in Dr. Saiful Anwar General Hospital
}

\section{Respon Klinis Pemberian Terapi Plasma Konvalesen pada Pasien COVID-19 di RSUD Dr. Saiful Anwar}

\author{
Niniek Budiarti ${ }^{1}$, Herwindo Pudjo $B^{1}$, Djoko Heri $H^{2}$, Putu Moda $A^{2}$ \\ ${ }^{1}$ Department of Internal Medicine Faculty of Medicine Universitas Brawijaya Malang \\ ${ }^{3}$ Department of Internal Medicine General Hospital Dr Saiful Anwar Malang
}

\begin{abstract}
The use of convalescent plasma has been beneficial for more than a century to treat various infections. The lack of effective treatment currently available for COVID-19 has reemerged the use of convalescent plasma as a potential therapeutic option. This is an observational descriptive study in 13 COVID-19 patient who got convalescent Plasma. Consist of 11 (84\%) male patient, 2 (16\%) female patient. Divided into two groups based on severity, and outcome. 38\% patient included in severe disesase and $62 \%$ patient in critically III condition. 30\% patient who got convalescent plasma deceased, and $70 \%$ had a resolve condition.
\end{abstract}

Keywords: COVID-19-Convalescent Plasma-reduce mortality

\begin{abstract}
Penggunaan plasma konvalesen telah bermanfaat selama lebih dari satu abad untuk mengobati berbagai infeksi. Kurangnya pengobatan efektif yang tersedia saat ini untuk COVID-19 telah memunculkan kembali penggunaan plasma konvalesen sebagai pilihan terapi yang potensial. Penelitian ini merupakan penelitian deskriptif observasional pada 13 pasien COVID-19 yang mendapatkan plasma konvalesen. Terdiri dari 11 (84\%) pasien laki-laki, 2 (16\%) pasien perempuan. Dibagi menjadi dua kelompok berdasarkan tingkat keparahan. $38 \%$ pasien termasuk dalam penyakit berat dan $62 \%$ pasien dalam kondisi kritis. $30 \%$ pasien yang mendapat plasma konvalesen meninggal, dan $70 \%$ dalam kondisi sembuh.
\end{abstract}

Kata Kunci: Konvalesen plasma COVID-19, penurunan kematian

Correspondence: Niniek Budiarti. Department of Internal Medicine Faculty of Medicine Universitas Brawijaya, Jl. Veteran Malang Tel. 08113655665Email: niniek.burhan123@gmail.com

DOI: http://dx.doi.org/10.21776/ub.jkb.2021.031.04.5 


\section{INTRODUCTION}

The pandemic in 2019-2020 is the coronavirus disease 2019 (COVID-19) pandemic caused by the severe acute respiratory syndrome coronavirus 2 (SARS-CoV-2), and it has created a significant disruption globally at all levels of healthcare provision. The disease was first reported in Wuhan, Hubei, China, in December 2019. Incubation period was reported 2-14 days after exposure to the virus. People with COVID-19 may have symptoms of coughing, shortness of breath or difficulty breathing, chills, muscle pain, fever, sore throat, and loss of taste or smell. Until now, no effective treatment for handling COVID-19 has been available.

The Coronavirus disease 2019 (COVID-19) epidemic has recently developed into a global public health concern with significant consequences (1). Early 2021, the World Health Organization (WHO) has announced $>100$ million confirmed cases of COVID-19, with more than 2 million deaths documented worldwide (2). In Indonesia, the number of COVID-19 cases continues increased to 6,243 people, cumulatively the number of positive cases has reached more than 1.6 million, and more than 44 thousand of them died. (3). This study is a part of national study which has a purpose about knowing the effectiveness of plasma convalescent therapy different COVID-19 severity.

\section{METHOD}

This was an observational descriptive study on confirmed COVID-19 patients undergoing convalescent plasma therapy at a tertiary hospital in Malang, Indonesia, from Mei 2020 until August 2020. The inclusion criteria used in this study were patients older than 18 years old, confirmed COVID-19 case, suffered from severe or critical illness of COVID-19, and agreed to participate in this study. Patient less than 18 years old and did not sign the informed consent was excluded in this study

Confirmed COVID-19 case was determined by positive RtPCR results from nasopharyngeal and oropharyngeal swabs. Severe illness of COVID-19 cases was defined as having shortness of breath with respiratory rate $\geq 30$ times/minute, oxygen saturation $\left(\mathrm{SpO}_{2}\right) \leq 93 \%$ within room air, $\mathrm{PaO}_{2} / \mathrm{FiO}_{2} \leq 300 \mathrm{mmHg}$, worsening chest X-ray $>50 \%$ in 24-48 hour. Critical illness of COVID-19 case was defined as having severe pneumonia, Acute Respiratory Distress Syndrome (ARDS) ration $\mathrm{PaO} 2 / \mathrm{FiO} 2<300$, requiring or using a mechanical ventilator, and suffering from septic shock and/or multi-organ failure. Each patient was given $200 \mathrm{cc}$ of convalescent plasma transfusion twice at a 12-hour interval and other therapy for COVID-19.

\section{RESULT}

The study was conducted in 13 COVID-19 patients consisting of $11(84 \%)$ males and 2 (16\%) females (Table 1$)$. The average age of COVID-19 sufferers in this study was 41.4 years (24-74 years). All patients given convalescent plasma had comorbidities. Of the 13 patients, 5 (28\%) were suffering from severe disease, and $8(62 \%)$ patients were suffering from critical illness. A total of 11 (70\%) patients in this study received good response therapy, while $4(30 \%)$ patients gave poor responses and died. This study also found that the majority of critically ill patients who received healing plasma ( 3 of 4 patients) had poor responses, while the majority of severe patients had a good response ( 6 of 7 patients) (Diagram 1 ).

Table 1. Patient characteristic

\begin{tabular}{|c|c|c|}
\hline & & $n=13(\%)$ \\
\hline \multirow[t]{2}{*}{ Gender } & Male & $11(84 \%)$ \\
\hline & Female & $2(16 \%)$ \\
\hline \multirow[t]{2}{*}{ Age } & Mean & 41,4 \\
\hline & Interval & $24-74$ \\
\hline \multirow[t]{2}{*}{ Severity of disease } & Severe & $5(38 \%)$ \\
\hline & Critically ill & $8(62 \%)$ \\
\hline \multirow[t]{2}{*}{ Outcome } & Death & $4(30 \%)$ \\
\hline & Resolved & $11(70 \%)$ \\
\hline
\end{tabular}

Outcome of Severe Disease

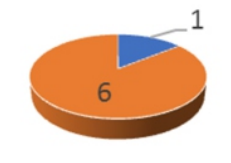

- death $=$ resolved

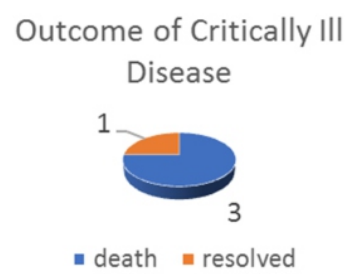

Diagram 1. Outcome of the disease

\section{DISCUSSION}

Until recently, no accurate, effective treatment for handling COVID-19 is available. The use of convalescent plasma is said to have benefits since several decades ago in 1900, convalescent plasma used in the Spanish flu pandemic was also used in the treatment of MERS-CoV and SARS-CoV with good results. Given the historical benefit and the absence of established antiviral therapy for SARS-CoV-2 (severe acute respiratory disease coronavirus 2), convalescent plasma therapy has been proposed as a treatment option for COVID-19. Several case reports and trials show the benefits of administration of plasma to COVID-19 patients. This report tried to observe further how plasma therapy responds to different degrees of COVID-19 disease severity.

Preliminary data analysis showed that in 5 critically ill patients conditions receiving conventional plasma therapy, only 1 patient had an improved outcome. Among 8 patients with severe degrees who received conventional plasma therapy, 7 patients showed an improvement in their condition and were discharged from the hospital. This result could be obtained because severe COVID-19 is characterized by an abundant pro-inflammatory response which later also called cytokine storm occurred earlier so that the addition of plasma may not provide more benefit.

This study showed that the majority of the COVID-19 patients (70\%) who received convalescent plasma therapy had good responses while only $30 \%$ of patients responded poorly and died. This indicated that convalescent plasma could be a promising therapy in COVID-19. There are several proposed mechanisms by which how convalescent 
plasma works. One of main work of convalescent plasma mechanism is the neutralizing effect $(4,5)$. Convalescent plasma also mediates other antibody functions, such as protection. As reported in case series of Wuhan, plasmatreated patients experienced large reductions in their serum viral load, and most become virus-negative three days after infusion. This observation shows that convalescent plasma has antiviral activity, which is crucial because it indicates that antibody administration have a biology effect. The other study shows that given the plasma shows that a decrease in viral load laters make into clinical improvement $(6,7,8)$. The other mechanism of plasma convalescent that might explain the improvement condition in every patient treated is because its immunomodulation effect. (9)

This study also revealed that most of the patients who had poor responses and died after convalescent plasma

\section{REFERENCES}

1. Cascella M, Rajnik M, Aleem A, Dulebohn SC, and Napoli RD. Features, Evaluation, and Treatment of Coronavirus (COVID-19). (Online) 2021 Jul 30. https://www.ncbi.nlm.nih.gov/books/NBK554776/

2. Wang C, Wang Z, Wang G, Lau JYN, Zhang K, and Li W. COVID-19in Early 2021: Current Status And Looking Forward. Signal Transduction and Targeted Therapy. 2021; 6(1): 1-14.

3. Muhyiddin and Nugroho H. A Year of Covid-19: $A$ Long Road to Recovery and Acceleration of Indonesia's Development. The Indonesian Journal of Development Planning. 2021; 5(2): 1-19.

4. Li L, Zhang W, Hu Y, et al. Effect of Convalescent Plasma Therapy on Time to Clinical Improvement in Patients With Severe and Life-threatening COVID19: A Randomized Clinical Trial. Journal of American Medical Association. 2020; 324(5): 460-470.

5. Rajendran K, Krishnasamy N, Rangarajan J, Rathinam J, Natarajan M, and Ramachandran A. Convalescent Plasma Transfusion for the Treatment of COVID-19: Systematic Review. Journal of Medical Virology. therapy had critically ill cases. As many as 3 (of 4) critically ill patients who received convalescent plasma had poor respond, while only 1 (of 7) severe patient had poor response. This condition could occur because, in critically ill patients, it is characterized by cytokine storm (10). Critically ill patients had advanced disease, some with multi-organ failures, which is not optimal for antibody therapy. Due to the lack of availability of convalescent plasma in this study, convalescent plasma was only given to patients with severely or critically ill patients. Therefore, convalescent plasma effects in mild or moderate cases of COVID-19 patients could not be evaluated. Another limitation of the study is the small number of patient that included in the study analysis.

This study shows that convalescent plasma therapy provides good results in COVID-19 disease. However, this effect is not shown in critically ill patients of COVID-19 disease.

6. Duan K, Liu B, Li C, et al. Effectiveness of Convalescent Plasma Therapy in Severe COVID-19 Patients. Proceedings of the National Academy of Sciences of the United States of America. 2020; 117(17): 94909496.

7. Shen C, Wang Z, Zhao F, et al. Treatment of 5 Critically III Patients with COVID-19 with Convalescent Plasma. Journal of American Medical Association. 2020; 323(16): 1582-1589.

8. Casadevall A, Joyner MJ, and Pirofski LA. A Randomized Trial of Convalescent Plasma for COVID-19-Potentially Hopeful Signals. Journal of American Medical Association. 2020; 324(5): 455457.

9. Rojas $\mathrm{M}$, Rodríguez $\mathrm{Y}$, Monsalve $\mathrm{DM}$, et al. Convalescent Plasma in Covid-19: Possible Mechanisms of Action. Autoimmunity Reviews. 2020; 19(7): 1-9.

10. Yuki K, Fujiogi M, and Koutsogiannaki S. COVID-19 pathophysiology: A review. Clinical Immunology. 2020; $215: 1-8$. 